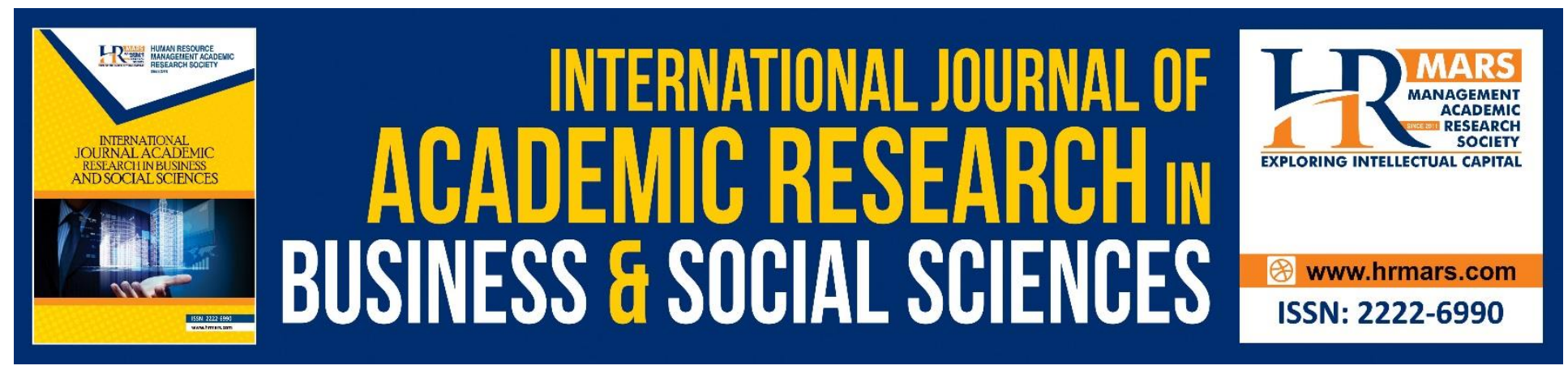

\title{
Factors Affecting Effectiveness of Cluster Business Management: A Case Study of Gift and Decorative Industry Club under Federation of Thai Industries
}

\section{Kingporn Thongba}

To Link this Article: http://dx.doi.org/10.6007/IJARBSS/v9-i5/5890

DOI: $10.6007 /$ IJARBSS/v9-i5/5890

Received: 16 March 2019, Revised: 07 April 2019, Accepted: 26 April 2019

Published Online: 30 May 2019

In-Text Citation: (Thongba, 2019)

To Cite this Article: Thongba, K. (2019). Factors Affecting Effectiveness of Cluster Business Management: A Case Study of Gift and Decorative Industry Club under Federation of Thai Industries. International Journal of Academic Research Business and Social Sciences, 9(5), 490-497.

Copyright: (C) 2019 The Author(s)

Published by Human Resource Management Academic Research Society (www.hrmars.com)

This article is published under the Creative Commons Attribution (CC BY 4.0) license. Anyone may reproduce, distribute, translate and create derivative works of this article (for both commercial and non-commercial purposes), subject to full attribution to the original publication and authors. The full terms of this license may be seen

at: http://creativecommons.org/licences/by/4.0/legalcode

Vol. 9, No. 5, 2019, Pg. 490 - 497

http://hrmars.com/index.php/pages/detail/IJARBSS

JOURNAL HOMEPAGE

Full Terms \& Conditions of access and use can be found at http://hrmars.com/index.php/pages/detail/publication-ethics 


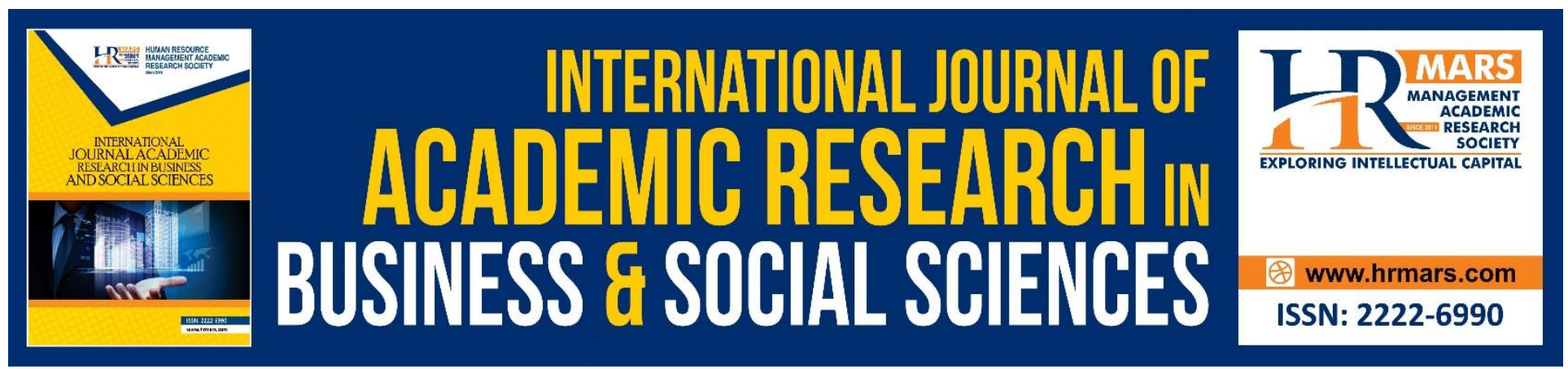

\title{
Factors Affecting Effectiveness of Cluster Business Management: A Case Study of Gift and Decorative Industry Club under Federation of Thai Industries
}

\author{
Kingporn Thongba \\ Sukhothai Thammathirat Open University, Nonthaburi Thailand \\ Kingporn07@gmail.com
}

\begin{abstract}
The purpose of this mixed methods research were (1) to study the effectiveness level of business cluster of Gift and Decorative Industry Club, The Federation of Thai Industries; (2) to examine external and internal factors, process and results of business cluster members; (3) to measure influences of external and internal factors and process; and (4) to propose business cluster management process of Gift and Decorative Industry Club that suits economic and social environment of Thailand. Qualitative data was collected by literature review from relevant documents and in- depth interviews of five executives of Gift and Decorative Industry Club and Lifestyle and Fashion Industry Cluster, while quantitative data was collected by 37 club members. The result found that effectiveness level of business cluster of Gift and Decorative Industry Club, the Federation of Thai Industries was at a low level. Most club members evaluated the effectiveness of cluster in each aspect, reduce cost, innovation, research and development and human resource development at low level and the marketing at medium level. Due to the low effectiveness of business clusters could not increase the competitive advantage. Moreover, the process factors of participation on strategic planning and implementing had influenced upon the effectiveness level of business cluster of Gift and Decorative Industry Club at $41.20 \%$. The business cluster executives should promote the participative process of strategic planning and implementing for members.
\end{abstract}

Keywords: Effectiveness of Business Cluster, Gift and Decorative Industry Club, Federation of Thai Industries

\section{Introduction}

A business cluster is a geographic concentration of interconnected businesses, suppliers, and associated institutions in a particular field. Clusters are considered to increase the productivity with which companies can compete, nationally and globally. Clusters are also very important aspects of strategic management (Wikipedia). The cluster concept has rapidly attracted attention from government since it was proposed in 1990 by Michael E. Porter in book title "The Competitive 
Advantage of Nations" (Porter, 1998). The book was based on studies of ten nations and argues that a key to national wealth and advantage was the productivity of firms and workers collectively, and that the national and regional environment supports that productivity. Porter proposed the "diamond" framework, a mutually-reinforcing system of four factors that determine national advantage: factor conditions; demand conditions; related or supporting industries, and firm strategy, structure and rivalry. Information, incentives, and infrastructure were also key to that productivity (Porter, 2001).The Conceptual Business Cluster was implemented in many countries (Ceglie and Dini, 1990).

After economic crisis of Thailand in decade 1990, Thai government policy was implementing the cluster concept to increase national competitive advantage (Department of Industry Promotion, 2004). The development of business clusters in Thailand were participated by public and private organizations. The Federation of Thai Industries (FTI) was also participated this policy. FTI had 43 clubs and 10 clusters Gift and Decorative Industry Club was the interesting club due to national trade goods production. This club was member in The Lifestyle and Fashion Cluster which was established in 2012. As being university lecturers, doing research was the important duty for teaching and social servicing. In teaching aspect, this research was to study factors that affecting effectiveness of business cluster and to evaluate the level of attainment of business cluster concept implementation. In social servicing, the research findings will be useful knowledge to those involved business.

\section{Methodology}

The purpose of this research were

(1) To study the effectiveness level of business cluster of Gift and Decorative Industry Club, The Federation of Thai Industries;

(2) To examine external and internal factors, process and results of business cluster members;

(3) To measure influences of external and internal factors and process affecting effectiveness of business cluster; and

(4) To propose business cluster management process of Gift and Decorative Industry Club that suits economic and social environment of Thailand.

Research conceptual framework integrated from literature review and shown as fig 1. 
INTERNATIONAL JOURNAL OF ACADEMIC RESEARCH IN BUSINESS AND SOCIAL SCIENCES

Vol. 9, No. 5, May, 2019, E-ISSN: 2222-6990 @ 2019 HRMARS

Environmental Factors

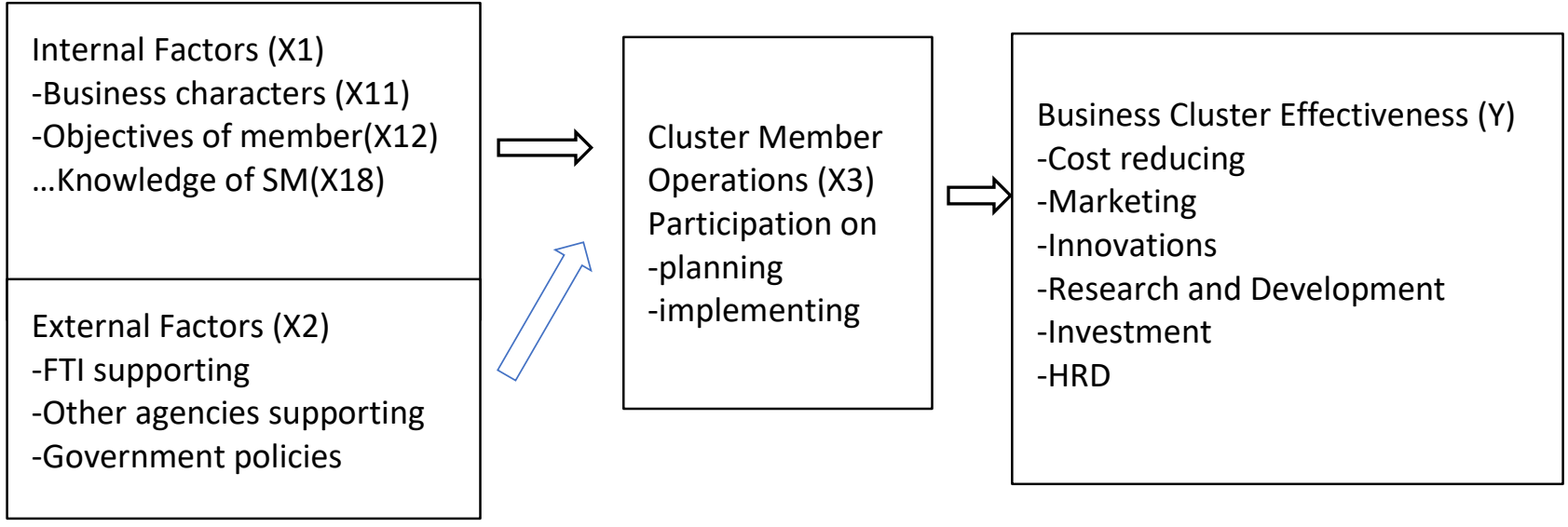

\section{Picture 1 Research Conceptual Framework}

This research was a mixed method of qualitative and quantitative research. Qualitative data was collected by litarature review from relevant documents and in- dept interviews of five executives of Gift and Decorative Industry Club and Lifestyle and Fashion Industry Cluster. Quantitative data was collected by 37 club members as the responsed rate of $59.68 \%$ of the total. For qualitative data analysis, content analysis and Diamond Model were adopted in this study. For quantitative data analysis, statistical tools for quantitative data analysis were employed including mean, standard deviation and multiple regression.

\section{Results}

Results derived from the research were showed that

1. The effectiveness level of business cluster of Gift and Decorative Industry Club, The Federation of Thai Industries.

The qualitative data assessed by the five executives of Gift and Decorative Industry club and Lifestyle and Fashion Cluster opinions were of moderate level, but the quantitative data from the club member opinions in mean of overall outputs were a low level (mean $=1.83$ ). The effectiveness of marketing aspect was highest level (mean $=2.86$ ). So, the overall effectiveness of business cluster of Gift and Decorative Industry Club, FTI was at a low level.

2. The environmental factors and process factors of business cluster of Gift and Decorative Industry Club, The Federation of Thai Industries. Environmental factors was divided to internal and external factors. The qualitative internal data and external data from in-dept interviews were analyzed by six aspects of Diamond Model. They showed both strengths and weaknesses in each aspect. The quantitative data of internal factors were analyzed by mean and percentage as showed in Table 1. 
INTERNATIONAL JOURNAL OF ACADEMIC RESEARCH IN BUSINESS AND SOCIAL SCIENCES Vol. 9, No. 5, May, 2019, E-ISSN: 2222-6990 @ 2019 HRMARS

Table 1 Mean and Percentage of Internal Factors of Business Cluster of Gift and Decorative Industry Club, The Foundation of Thai Industries

\begin{tabular}{|r|c|c|}
\hline Internal Factors & Range (Million Baht) & Mean (Million Baht) \\
\hline Business Characteristics & & 5.14 \\
Registered Capital (x11) & $1-36$ & 14.28 \\
Domestic Sales (x12) & $1-100$ & 4.00 \\
Foreign Sales (x13) & $0-15$ & 5.42 \\
Membership Age (x14) & $1-16$ & 64.84 non committee \\
Committee Status (x15) & $32.44 \%$ committee & 88.88 multiple \\
Business Type (x16) & $10.82 \%$ single & \\
\hline & & b multi objective \\
\hline Purpose of joining club (x17) & $37.84 \%$ networking & 27.00 medium \\
\hline Knowledge of SM (x18) & $67.80 \%$ high & \\
\hline
\end{tabular}

The analytical data of external factors which included mean of supporting from FTI, relating agencies and government policies, were $2.34,2.06$ and 2.80 . So, the overall results were at a low level.

The process factors assessed by the club member opinion in two parts, participation on strategy planning and in strategy implementing. The analytical data of overall participation process in strategic planning and strategic implementation of club members who respondents were at low level.

3. Influencing of external factors and process factor upon the effectiveness of business cluster were analyzed by Multiple Regression that show as table 2

Table 2 Coefficients of Internal Factors of Business Cluster of Gift and Decorative Industry Club, The Foundation of Thai Industries

\begin{tabular}{|c|c|c|c|c|c|c|}
\hline & \multicolumn{6}{|c|}{ Coefficients $^{a}$} \\
\hline & \multirow[t]{2}{*}{ Model } & \multicolumn{2}{|c|}{$\begin{array}{c}\text { Unstandardized } \\
\text { Coefficients }\end{array}$} & \multirow{2}{*}{$\begin{array}{c}\begin{array}{c}\text { Standardized } \\
\text { Coefficients }\end{array} \\
\text { Beta }\end{array}$} & \multirow[t]{2}{*}{$\mathbf{t}$} & \multirow[t]{2}{*}{ Sig. } \\
\hline & & B & Std. Error & & & \\
\hline \multirow[t]{11}{*}{1} & (Constant) & -.469 & 1.193 & & -.393 & .698 \\
\hline & $\mathrm{X}_{11}$ & .028 & .042 & .268 & .655 & .518 \\
\hline & $\mathrm{X}_{12}$ & -.004 & .016 & -.109 & -.273 & .787 \\
\hline & $\mathrm{X} 13$ & -.012 & .302 & -.007 & -.039 & .969 \\
\hline & $\mathrm{X}_{14}$ & .032 & .029 & .174 & 1.112 & .277 \\
\hline & $\mathbf{X}_{15}$ & .241 & .257 & .151 & .939 & .357 \\
\hline & $\mathbf{X}_{16}$ & .552 & .288 & .317 & 1.914 & .067 \\
\hline & $\mathrm{X}_{17}$ & -.436 & .356 & -.276 & -1.226 & .232 \\
\hline & $\mathrm{X}_{18}$ & .107 & .175 & .131 & .609 & .548 \\
\hline & $x_{2}$ & -.061 & .235 & -.060 & -.262 & .795 \\
\hline & $x_{3}$ & .447 & .121 & .640 & 3.694 & .001 \\
\hline
\end{tabular}


INTERNATIONAL JOURNAL OF ACADEMIC RESEARCH IN BUSINESS AND SOCIAL SCIENCES Vol. 9, No. 5, May, 2019, E-ISSN: 2222-6990 @ 2019 HRMARS

Model Summary

\begin{tabular}{|c|c|c|c|c|}
\hline $\begin{array}{c}\text { Mod } \\
\text { el }\end{array}$ & $\mathbf{R}$ & $\begin{array}{c}\mathbf{R} \\
\text { Square }\end{array}$ & $\begin{array}{c}\text { Adjusted R } \\
\text { Square }\end{array}$ & $\begin{array}{c}\text { Std. Error of } \\
\text { the } \\
\text { Estimate }\end{array}$ \\
\hline 1 & $.642^{\mathrm{a}}$ & .412 & .394 & .61546 \\
2 & $.699^{\mathrm{b}}$ & .489 & .458 & .58230 \\
\hline
\end{tabular}

a. Predictors: (Constant), $x_{3}$

b. Predictors: (Constant), $\mathrm{x}_{3}, \mathrm{x}_{16}$

Coefficients $^{\mathrm{a}}$

\begin{tabular}{|c|c|c|c|c|c|c|}
\hline \multicolumn{2}{|c|}{ Model } & \multicolumn{2}{|c|}{$\begin{array}{l}\text { Unstandardized } \\
\text { Coefficients }\end{array}$} & \multirow{2}{*}{$\begin{array}{c}\begin{array}{c}\text { Standardize } \\
\text { d } \\
\text { Coefficients }\end{array} \\
\text { Beta }\end{array}$} & \multirow[t]{2}{*}{$\mathbf{t}$} & \multirow[t]{2}{*}{ Sig. } \\
\hline & & B & Std. Error & & & \\
\hline \multirow[t]{2}{*}{1} & $\begin{array}{c}\text { (Constan } \\
\text { t) }\end{array}$ & .960 & .247 & & 3.890 & .000 \\
\hline & $\mathrm{x}_{3}$ & .448 & .092 & .642 & 4.877 & .000 \\
\hline \multirow[t]{3}{*}{2} & $\begin{array}{c}\text { (Constan } \\
\text { t) }\end{array}$ & .185 & .419 & & .441 & .662 \\
\hline & $x_{3}$ & .421 & .088 & .604 & 4.804 & .000 \\
\hline & $\mathrm{X}_{16}$ & .488 & .219 & .280 & 2.232 & .033 \\
\hline
\end{tabular}

a. Dependent Variable: $\mathrm{Y}$

From table 2, it showed that the participation of strategic implementation ( $x 3$ ) had influenced upon the effectiveness of business cluster of Gift and Decorative Industry Club at $41.20 \%(R=.412)$. Regression Equation model predicted $Y=0.960+0.448 \times 3$.

\section{Discussion}

The effectiveness level of business cluster of Gift and Decorative Industry Club, the Federation of Thai Industries was at a low level, it was consistent with the research finding of Netrapradit, Napawan and associated, (2014) in "The Effectiveness of Gift and Decorative Ceramic Manufacturer Group in Lampang Province". And it was consistent with the research finding of Wattanapankitti (2016) in "The Adaption to the AEC Free Trade of Ceramic Manufacturers in Lampang Province", which found the ceramic manufacturers had business cluster to networking and increasing productivity for international compete but the results were failed. Furthermore, this research finding was consistent with Suthiprabha (2012) in "Cluster to Enhance Business Competitiveness Advantage: a Case of Gem\& Jewelry Cluster in Chanta Buri Province" which found that the success of cluster development of Gem \& Jewelry businesses in Chanta Buri was not easy, even it was drived up but it had still lacked of networking and collaboration. The low effectiveness level of business cluster of Gift and Decorative Industry Club derived from the club member opinions, in quantitative data. Most club members 
evaluated the effectiveness of cluster in each aspect, reduce cost, innovation, research and development and human resource development at low level and the marketing at medium level. Due to the low effectiveness of business clusters could not increased the competitive advantage. It was consistent with Porter (1990), which said that business clusters were not autonomy occurred in geographic part of nations, but they were happened by relying on networking, connecting and effectiveness strategic management operating.

They were many factors affecting the effectiveness of business cluster of Gift and Decorative industry Club, the Foundation of Thai Industries. Based on qualitative data from the executives of industry club and business cluster that showed environment factors and participative process of strategic planning and implementing were influenced the effectiveness level of business cluster. This was consistent with Porter's Diamond Model (1998), the research finding of Kodchanan (2015) in "Foreign Experience of Cluster Development", and with Wutthikaro (2015),the former Permanent Secretary of Ministry of Industry, who said that business cluster was value chain management to increase the competitive advantage in three aspects, such as productivity, and creative entrepreneurs. Based on quantitative data analyzed by Multiple Regression , found that the process factors of participation on strategic planning and implementing and business type had influenced upon the effectiveness level of business cluster of Gift and Decorative Industry Club at $48.90 \%$. It was consistent with the research finding of Netpradit,Napawan and associated (2014), which effectiveness level of ceramic cluster in Lampang was influenced upon the knowledge management ,network management, production quality and marketing mix at $75.10 \%$.

\section{Conclusion}

The research finding that the effectiveness of Lifestyle and Fashion Cluster was at low level. Moreover based on regression model the result showed that the process factors of participative planning and implementing had influenced upon Effectiveness of business cluster $41.20 \%$ at the significant level $\alpha$ 0.05. Although the Gift and Decorative Club was 1 of 7 Club in Lifestyle and Fashion Cluster but the executives of cluster should promote the participative management for increasing effectiveness of business cluster.

\section{References}

Academic Focus Retrieved from http;///parliament.go.th/library

Ariyakajorn, P. (2013) "Cluster, Tool for Increasing Competitive Advantage : A Case Study of Metal Packing Industries Cluster in Bangkok." Master of Business Economics Thesis Faculty of Economics Thammasat University

Ceglie, G. and Dini, M. (1990) "SME. Cluster and Network Development in Developing Countries: The Experience of UNIDO" International Conference on Building a Model and Effective Development Service Industry for Small Enterprises, UNIDO 6

Department of Industrial Promotion. (2004) "Cluster" Retrieved from http:///info.dip.go.th/

Hatch, R. C. (2002) "Towards a Strategy for SME Cluster and Network Development in Thailand" A Discuss Paper for Stakeholders for the International Labor Office's Initiative on Business-toBusiness Networking Thailand

Kodchakorn, R. (2015) “Cluster : Business Grouping for Competition” 
INTERNATIONAL JOURNAL OF ACADEMIC RESEARCH IN BUSINESS AND SOCIAL SCIENCES

Vol. 9, No. 5, May, 2019, E-ISSN: 2222-6990 @ 2019 HRMARS

Porter, M. E. (1990) The Competitive Advantage of Nations London: Macmillan.

Porter, M. E. (1998), Clusters and the new economics of competition, Harvard Business Review, Nov/Dec98, Vol. 76 Issue 6, p77,

Porter, M. (1998). On Competition. Boston: Harvard Business School Press. p. 225. The Competitive Advantage of Nations. New York: The Free Press. 1-857 pgs.

Porter, M. (2001) 'Location, Competition, and Economic Development: Local Clusters in a Golbal Economy' Journal Economic Development Quarterly, vol 14, no.1, pp 15-34,

UNIDO (2001) "Development of Cluster and Networks of SMEs" Private Sector Development Branch Investment Promotion and Institutional Capacity Building Division.

Netpradit, N. (2014) “An Operational Effectiveness for Entrepreneurs' Management of Ceramic Industrial Handicrafts Product at Lampang Provincial Area" Journal of Association of Researchers vol.19 no. 1 January - April

Suthiprabha, T. (2012) Cluster to Enchance in Business Competitiveness Advantage: A Case Study of Gem and Jewelry Cluster in Chanta Buri Province. Innovation College, Thammasat University.

The Federation of Thai Industries "About F. T. I." Retrieved from www.fti.or.th/

Wattanapankitti, P. (2016) Adaptation to Support the Trade Liberallization ASEAN Economic Community for the Ceramic Entrepreneurs in Lampang Province . Faculty of Management Science, Rajabhat University (Lumpang).

Wheelen., T. L. and Hunger, D. J. (2012) Strategic Management and Policy : Toward Global Sustainability 13th Edition Prentice Hall

Wikipedia "Business Cluster" Retrieved fromhttps://en.wikipedia.org/wiki/Businesscluster

Wuthikaro, A. (2015) “ Executive Interview: Business Cluster Startup in Thailand” WEAR Journal vol.16 Oct.-Dec. pp 7-8 